\title{
Module of Integrated Insect Pest Management on Tomato With Growers' Participation
}

\author{
Gadi V. P. Reddy ${ }^{1} \&$ Khanobporn Tangtrakulwanich ${ }^{1}$ \\ ${ }^{1}$ Western Triangle Agricultural Research Center, Montana State University, Conrad, Montana, USA \\ Correspondence: Gadi V. P. Reddy, Western Triangle Agricultural Research Center, Montana State University, \\ Conrad, MT., Montana 59425, USA. Tel: 1-406-278-7707. E-mail: reddy@montana.edu
}

Received: February 8, 2014

Accepted: March 4, 2014 Online Published: April 15, 2014

doi:10.5539/jas.v6n5p10

URL: http://dx.doi.org/10.5539/jas.v6n5p10

\begin{abstract}
Tomato, Lycopersicum esculentum L. (Solanaceae), is an important vegetable crop in the Mariana Islands (Guam, Saipan, Rota and Tinian). Because tomato is heavily attacked by both the tomato fruitworm Helicoverpa armigera Hübner (Lepidoptera: Noctuidae) and the red spider mite Tetranychus marianae McGregor, research was begun in 2011 to develop an integrated pest management program to better protect the crop from these pests. Our previous studies have indicated nominal threshold levels for T. marianae to be 8-12 mites/leaf in the dry season and 8-14 mites/leaf during the wet season, while for $H$. armigera the threshold was found to be 2 eggs per 10 of the plants, followed by an additional pesticide application only if 2 damaged fruit or $H$. armigera larvae were detected per 50 immature fruits. Other studies have found the IPM package used here of petroleum spray oil (PSO), BotaniGard, neem, and DiPel applied 15, 30, 45 and 60 days after tomato transplant to be a viable approach, significantly reducing the pest complex and giving higher tomato yield compared to both the growers' current practice (carbaryl or malathion, 15 applications per cropping season) and control plots. The current field study was conducted at two locations in Guam (Yigo and Inarajan), USA, in 2012 and 2013 to compare this IPM package with the growers' current practice in larger plots designed to educate the growers. The IPM package significantly lowered the pest complex and gave higher tomato yield at both the locations. Tomato growers were invited to attend an informal IPM training program on December 16, 2013 at the University of Guam, which was attended by 48 growers from four Mariana Islands. Of these growers, 41 (85\%) were aware of and understood the risks associated with traditional insecticides and recognized the concept of using an IPM package in managing tomato pests before the workshop. However, all the attendees understood the concept and benefits of IPM after the workshop. Follow up with these tomato growers found that $35(73 \%)$ later adopted the IPM program using PSO, BotaniGard, and Dipel at 15, 30, 45 and 60 DAT in the Mariana Islands.
\end{abstract}

Keywords: integrated pest management, Tetranychus marianae, Helicoverpa armigera, tomato

\section{Introduction}

Growers in the Mariana Islands (Guam, Saipan, Rota, and Tinian) have been encouraged to increase vegetable production, including tomato, to reduce the importation of vegetables to the region and thus avoid the possible introduction of invasive plant and insect species (Reddy \& Tangtrakulwanich, 2013). Tomato growers who sell their products to local fresh markets mostly grow cherry tomatoes, which are grown in the Marianas year-round. In addition, tomatoes are traditionally grown as a backyard crop. While production of cherry tomatoes has expanded on commercial farms and in home gardens, crops have been widely damaged by the spider mite Tetranychus marianae McGregor (Acari: Tetranychidae) and the tomato fruit worm Helicoverpa armigera Hübner (Lepidoptera: Noctuidae). Although both pests attack right from seed bed to harvest, T. marianae damages most heavily during the early stage of the plant's life, while damage by $H$. armigera is most common during the later stage of the crop (from flowering until harvest).

Growers in the Mariana Islands use carbaryl and malathion insecticides to control T. marianae and H. armigera on eggplant and tomato (Reddy \& Miller, 2014; Reddy \& Tangtrakulwanich, 2013), and as many as 13-15 applications of these pesticides may be applied to each crop, greatly increasing both cost and exposure to pesticide residues. Furthermore, these applications do not effectively control these pests on tomatoes. Therefore, to reduce the reliance on miticides and insecticides and to educate the growers about integrated pest management (IPM), a 
research program was initiated in 2011 with funding from the United States Department of Agriculture-National Institute of Food and Agriculture (USDA-NIFA).

Our previous studies on developing an action thresholds for these pests indicated that based on the percentage of T. marianae-infested leaves, the incidence of T. marianae and yield levels, plots sprayed at 8-12 mites/leaf in the dry season and 8-14 mites/leaf during the wet season had significantly lower leaf damage and T. marianae densities compared to other possible threshold values, control plots, or those receiving regularly timed pesticide applications. Similarly, an initial spray scheduled when two eggs of $H$. armigera were detected on 10 plant samples, followed by an additional spray only if two damaged fruit or $H$. armigera larvae were detected per 50 immature fruit, resulted in lower percent fruit damage and higher marketable yield compared to other threshold levels or a regular spray schedule (Reddy \& Tangtrakulwanich, 2013).

Further field trials aimed at improving the management of these pests using an IPM package (petroleum spray oil (PSO), BotaniGard, neem, and DiPel) in treated plots, with applications at 15, 30, 45, and 60 days after transplant significantly reduced the number of T. marianae-infested leaves and the density of $T$. marianae compared to plots treated with carbaryl, malathion, six application of BotaniGard alone, six applications of DiPel alone, or untreated controls at both study locations (Reddy, G. V. P., unpublished data). Similarly, significantly lower fruit damage by H. armigera was recorded in plots treated with the IPM package than those treated with carbaryl, malathion, or the control treatments at both locations. Marketable tomato yields from the plots sprayed with the IPM package were significantly greater at both locations than were those in the other treatments.

The aim of the current study is to compare the relative efficacy of the IPM package (PSO, BotaniGard, neem and DiPel), which was found to be effective against $T$. marianae and $H$. armigera, with growers' current practice, to educate growers on the benefits of the IPM package, and to follow up on the rate of adoption of this IPM practice by the growers.

\section{Materials and Methods}

\subsection{Seedlings and Field Design}

Cherry tomato seeds were sown in trays $(40 \times 30 \mathrm{~cm})$, and seedlings were grown for 40 days in a nursery in a shade house $\left(30-32{ }^{\circ} \mathrm{C}, 60-80 \% \mathrm{RH}\right.$, and $14: 10 \mathrm{~h} \mathrm{~L}: \mathrm{D}$ photoperiod) using the standard agronomic practices of the area. Experiments were conducted at the University of Guam Agricultural Experiment Station at Yigo (N $13^{\circ}$ $\left.31.930^{\prime} \mathrm{E} 144^{\circ} 52.351^{\prime}\right)$ in northern Guam and at the Inarajan Experiment Station (N 13 61.963' E $\left.144^{\circ} 45.353^{\prime}\right)$ in southern Guam. Treatment plots $(15 \times 15 \mathrm{~m})$ were arranged in a randomized block design and separated from other plots by $1.0 \mathrm{~m}$ buffer zones to prevent contamination from spray drift. Identical trials were conducted from June-September 2012 at Yigo and August-November 2013 at Inarajan, Island of Guam (USA). Thirty five tomato seedlings that were 40 days old were transplanted with $75 \mathrm{~cm}$ spacing between rows and an average of $91.4 \mathrm{~cm}$ between plants within rows. Three replicates of each of the five treatments (Tables 1,2) produced a total of 15 plots for each experiment. Fertilizer applications followed that of Schulub and Yudin (2002). Treatments were the IPM package, two controls, and two growers practices (each being the repeated use of one insecticides, either carbaryl, or malathion).

\subsection{Treatment Measures}

The best treatment determined by our previous experiments (Reddy, G. V. P., unpublished data) was an IPM package (BotaniGard, PSO, neem and DiPel). In addition, a water spray control and a no spray control were applied to plots (Tables 1 and 2). Carbaryl and malathion applications were made in additional treatment plots at the time intervals generally practiced by Guam and other Micronesian growers. The amount of spray solution per application was $95 \mathrm{~L} /$ ha for small plants (up to 45 days after transplanting/DAT) and $190.0 \mathrm{~L} /$ ha for larger ones (45 DAT until harvest). All chemicals were applied with motorized backpack sprayers (Solo Brand; Forestry Suppliers, Jackson, Mississippi) equipped with an adjustable, flat spray, hollow cone, jet stream nozzle, with pressure $(45 \mathrm{psi}=310 \mathrm{kPa})$ calibrated to deliver 187 liters per hectare. 
Table 1. Information on the biological and chemical pesticides used in this study

\begin{tabular}{|c|c|c|c|}
\hline Treatment & Active Ingredient & Dose & Source \\
\hline Neem (Aza-Direct ${ }^{\circledR}$ ) spray & $\begin{array}{l}1.2 \% \text { Azadirachtin and other } \\
\text { ingredients } 98.8 \%\end{array}$ & $\begin{array}{l}10 \mathrm{ml} / 1 \text { liter } \\
\text { of water }\end{array}$ & $\begin{array}{l}\text { Azadirachtin, Gowan } \\
\text { Company, Yuma, AZ }\end{array}$ \\
\hline $\begin{array}{l}\text { Petroleum Spray Oil (Volck } \\
\text { oil spray }{ }^{\circledR} \text { ) }\end{array}$ & $\begin{array}{l}\text { Petroleum Oil 97\%, other } \\
\text { ingredients } 3 \%\end{array}$ & $\begin{array}{l}20 \mathrm{ml} / 1 \text { literof } \\
\text { water }\end{array}$ & $\begin{array}{l}\text { The Ortho Group, } \\
\text { Marysville, OH }\end{array}$ \\
\hline $\begin{array}{l}\text { BotaniGard (BotaniGard }{ }^{\circledR} \\
\text { 22WP) }\end{array}$ & $\begin{array}{l}\text { Beauveria bassiana Strain GHA } \\
22 \% \text {, inert ingredients } 78 \%\end{array}$ & $\begin{array}{l}2.4 \text { grams } / 1 \\
\text { liter of water }\end{array}$ & $\begin{array}{l}\text { Laverlam International } \\
\text { Corporation, Butte, MT }\end{array}$ \\
\hline DiPel (DiPel® DF) & $\begin{array}{l}\text { Bacillus thuringiensis, subsp. } \\
\text { kurstaki, strain ABTS-351, } \\
\text { fermentation solids, spores, and } \\
\text { insectidial toxins } 54 \% \text {; Other } \\
\text { ingredients } 46 \%\end{array}$ & $\begin{array}{l}15 \text { grams/1 } \\
\text { liter of liter }\end{array}$ & $\begin{array}{l}\text { Valent USA, Libertyville, } \\
\text { IL }\end{array}$ \\
\hline Carbaryl (Carbaryl 50 WP) & $\begin{array}{l}\text { 1-Naphthyl N-methyl carbamate } \\
50 \% \text {, Inert Ingredients } 50 \%\end{array}$ & $\begin{array}{l}43 \text { grams/1 } \\
\text { liter of water }\end{array}$ & AllPro, St. Joseph, MO \\
\hline Malathion (Prentox $®)$ & $\begin{array}{l}\text { Malathion } 0,0 \text {-dimethyl } \\
\text { phosphorodithioate of diethyl } \\
\text { mercaptosuccinate } 57 \% \text {, other } \\
\text { ingredients } 43 \%\end{array}$ & $\begin{array}{l}5 \mathrm{ml} / 1 \text { liter of } \\
\text { water }\end{array}$ & $\begin{array}{l}\text { Prentiss Incorporated, } \\
\text { Floral Park, NY }\end{array}$ \\
\hline Control (no water) & - & - & - \\
\hline Control (water spray) & - & Tap water & - \\
\hline
\end{tabular}

Table 2. Timing of the biological and chemical treatments imposed on tomato fields

\begin{tabular}{ll}
\hline Treatment & $\begin{array}{l}\text { Timing of treatment application (Days after } \\
\text { transplanting }\end{array}$ \\
\hline T1: Control (no applications) & - \\
T2: Control (water spray) & - \\
T3: Sequential application of BotaniGard, Petroleum spray oil & $15,30,45$ and 60 \\
(PSO), neem, DiPel (the IPM package) & \\
$\begin{array}{l}\text { T4: Sequential application of Malathion, 15 applications (the } \\
\text { growers practice) }\end{array}$ & $10,20,30,40,50,60,70,80,90,100,110$, \\
T5: Sequential application of Carbaryl, 15 applications (the & $120,130,140$, and 150 \\
growers practice) & $10,20,30,40,50,60,70,80,90,100,110$, \\
\hline
\end{tabular}

\subsection{Insect Sampling, Damage and Tomato Yield Assessments}

To determine T. marianae population levels, 10 plants were randomly selected per plot three leaves were checked on each-one from the top, middle and bottom of the plant (Reddy et al., 2013). On the underside of each leaf, mites were counted using a magnifying lens. Leaf counts were repeated weekly, and the number of leaves infested by T. marianae of the 30 leaves examined per plot was also recorded.

The egg and larval densities of $H$. armigera were estimated nondestructively in each tomato plot weekly. Egg densities were estimated by examining the plant's terminal from the tip down to the first fully expanded compound leaf, plus the third leaf down from the terminal, on 10 randomly selected plants in each plot (Kuhar et al., 2006). Larval infestation levels of $H$. armigera were estimated by randomly examining 60 unripe fruit per plot (one fruit per plant) and recording numbers of larvae as well as the number of damaged fruit.

The plots were harvested when fruit was ready and the yield was recorded for each plot.

The data were averaged and expressed as the number of mites per leaf, the percent of infested leaves, and the number of damaged fruits by $H$. armigera, and fruit yield per hectare. 


\subsection{Training Growers and Stakeholders About Integrated Pest Management Methods}

Tomato growers were invited to attend an informal training program on December 16, 2013 about IPM methods, which was conducted in cooperation with the Cooperative Extension Units of the University of Guam. This program aimed to inform growers of the risks associated with conventional insecticides and to illustrate the benefits of ecologically sound IPM methods, including those from the adoption of reduced-risk insecticides.

\subsection{Follow Up With Growers After a Training Program}

Two months after the training program, the attendees were surveyed for long- term gains in their knowledge of tomato cultivation and reduced-risk insecticide practices. The impact of the training program on adoption of reduced-risk insecticides are measured by a survey of tomato growers who participated in the training. These attendees were evaluated whether or not for showing an interest, recognizing the concept of using IPM methods and implementing IPM methods after the training.

Table 3. Follow up with tomato growers after the training program

\begin{tabular}{|c|c|c|c|c|c|c|}
\hline Subjects & Guam & Rota & Saipan & Tinian & Total & $\begin{array}{c}\text { Overall } \\
\text { Results (\%) }\end{array}$ \\
\hline Total number of growers who attended & 22 & 12 & 10 & 4 & 48 & - \\
\hline $\begin{array}{l}\text { Total number of growers that have shown an interest in } \\
\text { and recognized the concept of using IPM methods } \\
\text { (BEFORE the workshop) }\end{array}$ & 18 & 10 & 9 & 4 & 41 & 85 \\
\hline $\begin{array}{l}\text { Total number of growers that have shown an interest in } \\
\text { and recognized the concept of using IPM methods } \\
\text { (AFTER the workshop) }\end{array}$ & 18 & 10 & 9 & 4 & 41 & 100 \\
\hline $\begin{array}{l}\text { Total number of growers that had implemented IPM } \\
\text { methods }\end{array}$ & 15 & 9 & 8 & 3 & 35 & 73 \\
\hline
\end{tabular}

\subsection{Statistical Analysis}

Data for the number of mite-infested leaves per plot and proportion of damaged fruit among treatments, and overall yield levels in different treatments were analyzed using repeated measures ANOVA $(P<0.05)$ over multiple dates, and differences between treatments means were compared using the Tukey HSD test. Proportion data were square-root transformed prior to analysis in order to homogenize the variance. All statistical analyses were carried out using SAS Version 9.3 (SAS Institute 2011). The 5\% level of significance was used for all analyses. Training growers and stakeholders about IPM methods were analyzed by comparing the percentage of attendees who expressed the interest, recognition of the concept of using IPM, and implementing IPM methods at the time before and after the workshop was conducted.

\section{Results}

\subsection{Damage Assessment}

In plots treated with the IPM package (PSO, BotaniGard, neem, and DiPel) at 15, 30, 45 and 60 DAT, the number of $T$. marianae-infested leaves $\left(F_{4,11}=15.2, P<0.05\right.$; Figure 1$)$ and the number of mites per leaf $\left(F_{4,24}=41.3, P<\right.$ 0.05 ; Figure 1) were both significantly lower than in plots treated with carbaryl, malathion, or control plots at both locations. Significantly lower fruit damage by $H$. armigera was recorded in plots treated with the IPM package compared to the carbaryl or malathion treated plots and to both controls at both locations $\left(F_{4,26}=16.71, P<0.05\right.$; Figure 2). 

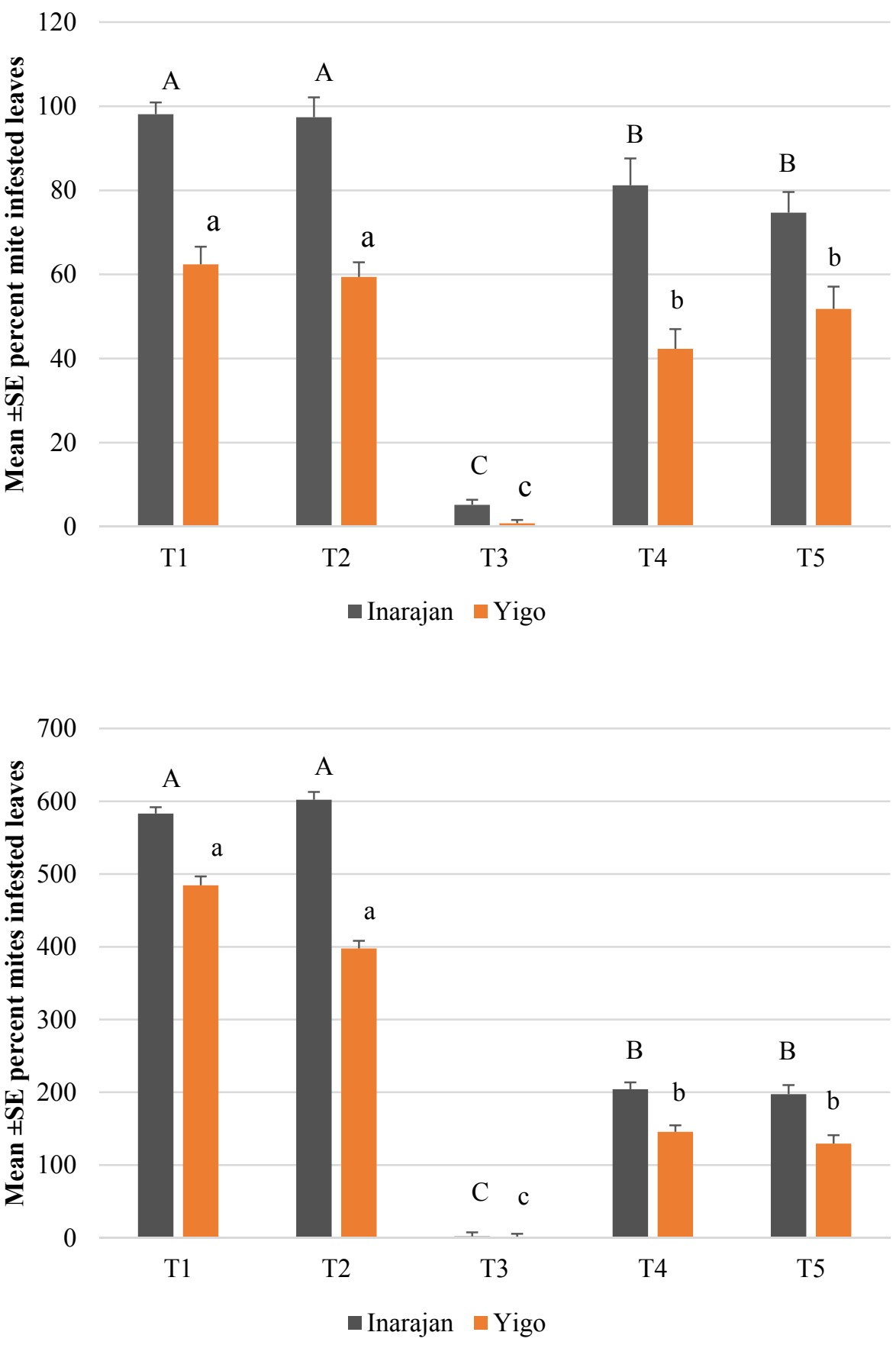

Figure 1. Percentage of mite damaged leaves and mean number of Tetranychus marianae in different treatments imposed on tomato. Means within the same column followed by the same letter are not significantly different $P>0.05$ (Repeated measure ANOVA, Tukey HSD). T1: Control (no applications); T2: Control (water spray); T3: Petroleum spray oil (PSO), BotaniGard, neem, DiPel (the IPM package); T4: Malathion, 15 applications (the growers' practice); T5: Carbaryl, 15 applications (the growers' practice). Each value represents the mean ( \pm SE) of three replications. The mean number of infested leaves and mean number of T. marianae per plot was recorded out of the 30 leaves counted in each plot 


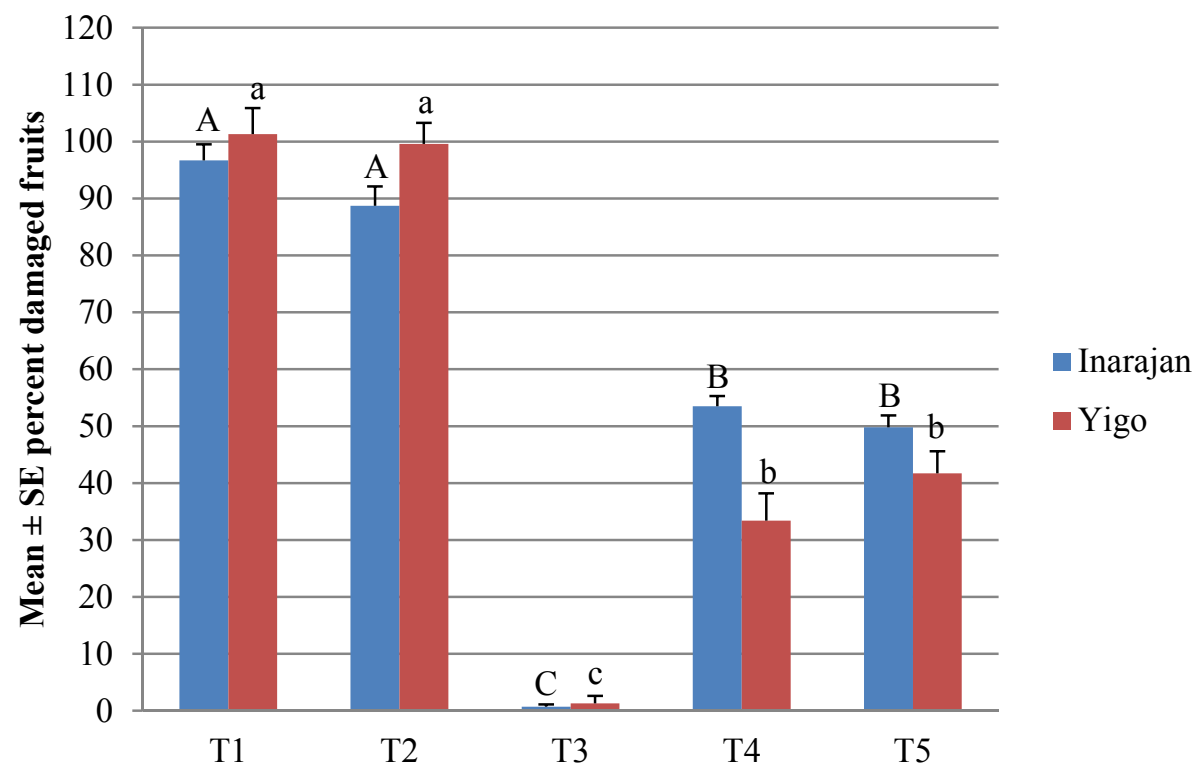

Figure 2. Percentage of fruit damage to tomatoes by Helicoverpa armigera in different treatments. Different letters above the bars indicate significant differences, $P<0.05$ (Repeated measure ANOVA, Tukey HSD). Each value represents the mean ( $\pm \mathrm{SE}$ ) of 3 replications. T1: Control (no applications); T2: Control (water spray); T3: Petroleum spray oil (PSO), BotaniGard, neem, DiPel (the IPM package); T4: Malathion, 15 applications (the growers' practice); T5: Carbaryl, 15 applications (the growers' practice)

\subsection{Yield Assessment}

The control plots suffered the highest damage from $T$. marianae and H. armigera and recorded the lowest marketable yield. The marketable tomato yields from the plots managed with the IPM package were significantly greater at both locations than those in other treatments $\left(F_{4,16}=11.47, P<0.05\right.$; Figure 3$)$.

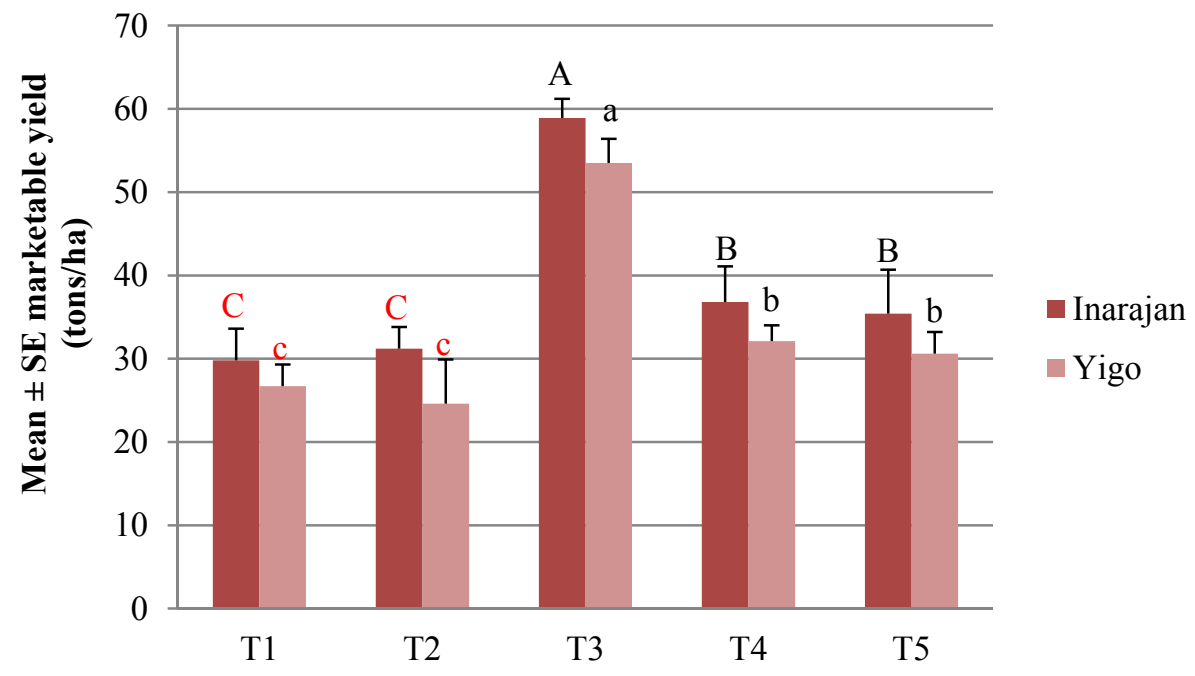

Figure 3. Marketable yield of tomatoes in different treatments. Different letters above the bars indicate significant differences, $P<0.05$ (Repeated measure ANOVA, Tukey HSD). Each value represents the mean ( $\pm \mathrm{SE}$ ) of 3 replications. T1: Control (no applications); T2: Control (water spray); T3: Petroleum spray oil (PSO), BotaniGard, neem, DiPel (the IPM package); T4: Malathion, 15 applications (the growers' practice); T5: Carbaryl, 15 applications (the growers' practice) 


\subsection{Training Program Follow Up}

The IPM training program provided information to growers about the threats associated with traditional insecticides and the benefits of the IPM package, including low risk insecticides. The training program was attended by 48 growers from four Mariana Islands, of whom 41 (85\%) were already aware of and understood the risks associated with the traditional insecticides and recognized the concept of using an IPM package in managing tomato pests (Table 3 ) before to the workshop. However, all the attendees understood the concept and benefits of IPM after the workshop. Follow up with tomato growers found that 35 of the growers $(73 \%)$ actually implemented the IPM program using PSO, BotaniGard, neem and DiPel at 15, 30, 45 and 60 DAT in the Mariana Islands.

\section{Discussion}

Even though implementing a pest management program based on numerical threshold levels is always superior and more cost effective than use of a calendar-based spray schedule (Reddy \& Tangtrakulwanich, 2013), pest action threshold levels were not available when we initiated this study. Additionally, there was an urgency to develop an effective control method in the Pacific Islands for $T$. marianae and $H$. armigera to replace the conventional sprays. Not all growers want to adopt threshold-based sprays since it is labor intensive and difficult to plan the work. Many growers do not want to count mites and assess fruit damage in the field.

Our previous and current studies have indicated that the IPM package of PSO, BotaniGard, neem and DiPel sprayed 15, 30, 45 and 60 days after transplant was a viable approach, significantly reducing the pest complex and providing a higher tomato yield compared to the growers' current practice (carbaryl or malathion, 15 applications) or to control plots. This IPM training program provided to the growers was effective can be seen by the fact that $100 \%$ of the attendees recognized the importance of changing their practices, and $73 \%$ of them actually implemented the IPM program suggested above. The development and implementation of IPM technologies on tomato has already significantly increased yields in various countries. Ehler (2006) mentioned that IPM recognition has been increasing that includes the use of reduced-risk pesticides. Over the past 35 years, IPM has become a valued model for establishing research and extension efforts worldwide. For example in India, Gajanana et al. (2006) reported that IPM technology has increased tomato yields on IPM farms by 46 percent, reduced the cost of cultivation by 21 percent, and increased net return by 119 percent.

In this study we used biorational insecticides, reported to be low risk. According to Schuster and Stansly (2012), the "biorationality" of an insecticide is almost always relative, i.e., the toxicity of one insecticide is compared to that of other insecticides, and is almost never broad spectrum, i.e., they are innocuous to one natural enemy or even some life stages of a natural enemy but toxic to another natural enemy or other life stages. In addition, soaps/detergents, oils and botanicals such as neem products (made with azadirachtin extracted from neem tree seeds) and entomopathogens have been likewise been conventionally termed biorational.

In the present study we did not notice any phytotoxicity on tomato plants due to the application of PSO. Narrow-range PSO applied as foliar sprays are now a vital component of IPM programs (Beattie, 1990; Davidson et al., 1991; Smith et al., 1997). However, the unstable quality of some of these products and their potential phytotoxicity has limited their use (Chen, 1988). PSO with a greater insecticidal efficacy usually results in a greater risk of phytotoxicity (Furness \& Maeizer, 1981). We believe that phytotoxicity may occur due to repeated applications of PSO. This is not the case in this study, where only one application of PSO was made. On the other hand, Rae et al. (2000) reported that there was no evidence of phytotoxicity of multiple applications of PSO on sweet orange trees. Similarly, our previous studies (Reddy \& Bautista, 2012) found no evidence of toxicity of PSO to eggplants.

\section{Conclusions}

The IPM package including the reduced-risk commercially available products (BotaniGard, PSO, neem, DiPel), applied at 15,30, 45 and 60 days after transplanting was effective and provided a significantly higher yield compared to the growers' practice currently used for controlling the pest complex on tomato in the Mariana Islands. These IPM tactics can be adapted to other tomato growing areas.

\section{Acknowledgements}

This project was supported initially by FY 2011 USDA's Pest Management Alternatives Program (PMAP), and the Grant Award No 2011-34381-30732 Special Research Grants Program - Competitive to the University of Guam. This project was transferred to the Montana State University (Award No 2011-34381-20051) under Project Director Transfer from the University of Guam. The USDA is an equal opportunity provider and employer. We thank D. M. H. Mantanona and R. Gumataotao for their help in the field. 


\section{References}

Beattie, G. A. C. (1990). Citrus Petroleum Spray Oils Agfact H2.AE.5 (Sydney: NSW Agriculture and Fisheries).

Chen, D. M. (1988). Mineral oil applied in citrus pests' control. China Citrus, 17, $29-31$.

Davidson, N. A., Dibble, J. E., Flint, M. L., Marker, P. J., \& Guye, A. (1991). Managing insects and mites with spray oils. University of California, Statewide Integrated Pest Management Project. IPM Education and Publications. Publ. (No. 33471-47).

Ehler, L. (2006). Integrated pest management (IPM): definition, historical development and implementation, and the other IPM. Pest Management Science, 62, 787-789. http://dx.doi.org/10.1002/ps.1247

Furness, G. O., \& Maelzer, D. A. (1981). The phytotoxicity of narrow distillation range petroleum spraying oils to Valencia orange trees in South Australia. Part I: The influence of distillation temperature and spray timing on yield and alternate cropping. Pesticide Science, 12, 593-602. http://dx.doi.org/10.1002/ps.2780120602

Gajanana, T. M., Krishna Moorthy, P. N., Anupama, H. L., Raghunatha, R., \& Prasanna Kumar, G. T. (2006). Integrated pest and disease management in tomato: An economic analysis. Agricultural and ResourceEconomics Review, 19, 269-280.

Kuhar, T. P., Nault, B. A., Hitchner, E. A., \& Speese III, J. (2006). Evaluation of action threshold based insecticide spray programs for tomato fruit worm management in fresh market tomatoes in Virginia. Crop Protection, 25, 604-612. http://dx.doi.org/10.1016/j.cropro.2005.08.016

Rae, D. J., Watson, D. M., Huang, M. D., Cen, Y. J., Wang, B. Z., Beattie, G. A. C., ... Liu, D. G. (2000). Efficacy and phytotoxicity of multiple petroleum oil sprays on sweet orange (Citrus sinensis (L.)) and pummelo (C. grandis (L.)) in Southern China. International Journal of Pest Management, 46, 125-140. http://dx.doi.org/10.1080/096708700227499

Reddy, G. V. P., \& Bautista, J. R. (2012).Integration of the predatory mite Neoseiuluscalifornicusand petroleum spray oil for control of Tetranychusmarianae on eggplant. Biocontrol Science and Technology, 22, 1211-1220. http://dx.doi.org/10.1080/09583157.2012.719152

Reddy, G. V. P., \& Miller, R. H. (2014). Field evaluation of petroleum spray oil and carbaryl against the red spider mite (Acari: Tetranychidae) on eggplant. Florida Entomologist, 97, 108-113.

Reddy, G. V. P., \& Tangtrakulwanich, K. (2013). Action threshold treatment regimens for red spider mite and fruit borer on tomato. Florida Entomologist, 96, 1084-1096. http://dx.doi.org/10.1653/024.096.0348

Reddy, G. V. P., Kikuchi, R., \& Bautista, J. R. (2013).Threshold-based spraying decision programs for the red spider mite Tetranychusmarianae on eggplant. Journal of Applied Entomology, 137, 429-436. http://dx.doi.org/10.1111/jen.12007

SAS Institute. (2011). SAS/STAT user's guide, version 9.3 for windows, SAS Institute, Cary, NC.

Schulub, R., \& Yudin, L. (2002). Eggplant, Pepper, and Tomato Production Guide for Guam. Guam Cooperative Extension, University of Guam, 188p.

Schuster, D. J., \& Stansly, P. A. (2012). Biorational Insecticides for Integrated Pest Management in Tomatoes. University of Florida IFAS Extension, ENY684 6p.

Smith, D., Beattie, G. A. C., \& Broadley, R. (1997). Citrus Pests and Their Natural Enemies: Integrated Pest Management in Australia (Brisbane, Queensland: Department of Primary Industries).

\section{Copyrights}

Copyright for this article is retained by the author(s), with first publication rights granted to the journal.

This is an open-access article distributed under the terms and conditions of the Creative Commons Attribution license (http://creativecommons.org/licenses/by/3.0/). 